\title{
Real-Time Performance Analysis and Operation \& Maintenance Experience of Photovoltaic Generating Plant in Western India
}

\author{
Jaya Vasita ${ }^{1}$, Akash Davda ${ }^{2}$ \\ ${ }^{1}$ Gujarat Energy Research and Management Institute, Pandit Deendayal Petroleum University, Gandhinagar 382007, India \\ ${ }^{2}$ Solar Energy Research Wing, Gujarat Energy Research and Management Institute, Innovation and Incubation Center, Gandhinagar 382007, \\ India
}

\begin{abstract}
Solar Photovoltaic (PV) technology is boosting up exponentially in recent decades as compared to the other solar energy harvesting technologies for the use of mankind. This study is conducted on the 1MW grid-connected solar PV power plant installed at Gandhinagar (Gujarat, Western India). The plant has started operation from the year 2011 and recently passed the 5-year milestone of constant operations. Data-sets on electricity production were collected for three years 2013, 2014 and 2015 and compared under actual climatic conditions. The final energy yield and performance ratio is obtained annually under real weather conditions. Despite the fact that maintaining the solar PV plant, there are several breakdown events due to inappropriate climatic conditions, electrical disruption, installation and maintenance practices, the estimated harvest is not cultivated from the solar PV. This study shows an assessment of operating experience including performance, maintenance, costs and failure events as well as various PV operating and maintaining issues encountered during various observations in the year 2015 and its effect on plant's operational capacity. The total Mean time between failures (MTBF) is calculated as $72.60 \mathrm{hrs}$ and Mean time to repair (MTTR) is calculated as $0.39 \mathrm{hrs}$. The availability of the plant for the year 2015 was calculated as $99.46 \%$.
\end{abstract}

Keywords: Large grid connected solar PV system, field performance evaluation, electricity production, operation \& maintenance, availability

\section{Introduction}

The rising energy demand in developing nation has elicited the issue of energy security. Renewable energy resources are the appropriate selection for assurance of green energy benefits. In the last decade, solar energy has emerged as a promising renewable energy resource and an alternative to other nonrenewable energy resources (coal, oil etc.). Thriving on this, various technologies are invented and installed to harvest the same. Presently, solar energy is probably the strongest growing electricity generating technology worldwide. In India, the recent target of $8.72 \mathrm{GW}$ was met in the year 2016 consisting of grid-connected remote power supplies [1]. India has a substantial amount of solar radiation throughout the year. So, the solar source might be suitable amongst all energy sources. Solar energy can be utilized in two ways, i.e. by direct conversion and indirect conversion. In indirect conversion solar energy is utilized for either heating or cooling of air and water (i.e. solar thermal). In direct conversion, the solar energy is directly converted into electricity by using solar photovoltaic technology [2], [3].

Among the several PV technologies available, Si wafer based technology is commonly used [4]. World PV market is shining up on an enormous scale so we need one of the most lucrative techniques for securing reliability, performance, safety and power competence. The PV module performance is a convoluted capacity of miniaturized scale climatic parameters in an external environment and working temperature assumes a perilous part in evaluating determination. Recently, various studies related to performance monitoring, maintenance, failure events and quality analysis of grid-connected PV power plants have been focused. Energy shortage is due to inequity between energy production and energy requirement. So, it is very indispensable to make a comparison of performance evaluation and availability analysis of solar PV power plants under actual climatic conditions [5]-[8]. Plant's Operation and Maintenance $(\mathrm{O} \& \mathrm{M})$ is considered as one of the key feat factors for solar PV power plant. O\&M includes securing decisions and actions regarding the control and upkeep of property amdleqqippmantoQ\&MAadilitates to sustain plant's fertility byymmimimminzinigzexpepsixeiequipment's malfunction and maintain unremitting functioning and energy production intensity [9].

Superiority in maintenance applications allocates generation of substantial energy investments and expenditure payback. The installed Photovoltaic power plant will transmit the maximum return on investment (ROI) if it runs even throughout over its era. Overall, there is a need to oblige for maximum yield from most favorable operations [10]. Universally there is a widespread confidence that solar power plants demand exceptionally less or no maintenance at all. This statement, in fact, comes out to be true, but at the same time also a bit misleading [11]. Solar power plant is an asset that is likely to last for almost 20-25 years of constant functioning.

Ultimately when it comes down to capital in order to calculate the correct Return on investment (ROI) one must account for O\&M issues and at the same time deal with these issues in

Volume 6 Issue 1, January 2017 


\section{International Journal of Science and Research (IJSR) \\ ISSN (Online): 2319-7064 \\ Index Copernicus Value (2015): 78.96 | Impact Factor (2015): 6.391}

most efficient and cost effective way. In the present study operating experience of 1 mega-watt, the grid-connect solar power plant is studied during this tenure; a substantial lesson has been learned about performance, maintenance, costs and failure events.

\section{Experimental Facilities}

The 1MW solar PV plant is located at Gandhinagar (Gujarat, Western India). Its geographical location is $23.22^{\circ} \mathrm{N}$ latitude and $72.68^{\circ} \mathrm{E}$ longitude and at an altitude of $81 \mathrm{~m}$ above sea level. At this site, the geographical conditions are suitable for solar power generation throughout the year. The geographical coordinates of the site are shown in Table 1. The environment conditions in terms of temperature, radiation, humidity and wind speed are suitable throughout the year. All PV modules are mounted south-facing with a tilt angle of $22.22^{\circ}$. The ventilation system is installed in an inverter room to defend it from the unpleasant temperature fluctuations. Acquired AC output is connected to the main distribution transformer with a capacity of $11 \mathrm{kV}$ that is directly connected to the grid. In this plant, two different module technologies are used; they are Multicrystalline Silicon (mc-Si) and Amorphous Silicon (a-Si) respectively. The data generated at $1 \mathrm{MWp}$ solar PV plant is standardized for $500 \mathrm{kWp}$ for both techniques. A single multicrystalline silicon PV module can generate $226 \mathrm{Wp}$ with $7.71 \mathrm{~A}$ of IMP $29.25 \mathrm{~V}$ of VMP. Amorphous silicon PV module can generate $140 \mathrm{Wp}$ with $2.25 \mathrm{~A}$ of IMP $62.3 \mathrm{~V}$ of VMP. PV modules are connected in series and parallel connections and further connected to the inverter of $600 \mathrm{~V}$ DC with the output of $315 \mathrm{~V} \mathrm{AC}$, which is further stepped up to $415 \mathrm{~V} \mathrm{AC}$. The protection boxes are installed in each row and its output is fed to the generator junction box. The attained $\mathrm{AC}$ output is connected to main distribution box to vacate power at $11 \mathrm{kV}$ for direct feeding into grid from where it is further transmitted

Table 1: Geographical details of the site

\begin{tabular}{|c|c|}
\hline Gujarat, Western India & Site name \\
\hline $23.22^{\circ} \mathrm{N}$ & Latitude \\
\hline $72.68^{\circ} \mathrm{E}$ & Longitude \\
\hline $81 \mathrm{~m}$ & Altitude \\
\hline $\mathrm{UTC}+05: 30$ & Time Zone \\
\hline $12^{\circ} \mathrm{C}$ to $49^{\circ} \mathrm{C}$ & Temperature Range \\
\hline
\end{tabular}

\section{Methodology for Performance Evaluation of the PV System}

This section describes the methodology for performance analysis of a grid-connected solar PV system. Multiple parameters are used to define the performance of PV plant. International Energy Agency (IEA) photovoltaic power systems program as termed in the IEC standard 61724 [12] provides the basic method to comprehend that the system performance is meeting anticipations.

Key performance parameters include - annual final yield, reference yield, performance ratio and Capacity utilization factor. These parameters have constructed the objectives for performance, operation, and maintenance [10]. Manually considered parameters are used to evaluate the performance of the PV plant.

\subsection{Total average energy generated by PV plant}

$$
\mathrm{E}_{\mathrm{t}}=\sum_{m=J a n}^{D e c} E m
$$

Where $\mathrm{m}=$ Jan, Feb......Dec.

Energy generated by PV plant is analyzed and monitored on 15 minutes' time interval. Therefore, average monthly energy production is obtained on a monthly and annual basis. It is the actual energy generated by the PV plant.

\subsection{Reference energy generated by PV plant}

$$
\mathrm{E}_{\mathrm{r}}=\mathrm{H}_{\mathrm{t}} * \mathrm{~A}^{*} \dot{\eta}
$$

Estimated energy is obtained by considering actual data of weather monitoring system placed at the location. Ambient temperature sensor used for measurement had an accuracy of $\pm 1 \%$. Solar irradiance sensor had an accuracy of $\pm 5 \%$ and a resolution of $1 \mathrm{~W} / \mathrm{m}^{2}$.

\subsection{Performance ratio (PR)}

PR is the total energy generated by PV plant divided by the reference energy generated by PV plant. It is the dimensionless quantity and also known as the quality factor. It represents the overall losses in the solar PV system during conversion from AC to DC output. Output deprivation is in equation with the geographical location, climatic conditions, $\mathrm{AC}$ and DC wiring, mismatch losses, temperature losses, radiation losses, inverter losses, as well as various issues related to plant O\&M.

$$
P R=\frac{E_{t}}{E_{r}}
$$

\subsection{Capacity utilization factor (CUF)}

CUF is the output power of the plant over a period of one year and its output if it had operated at nominal power in continuous operation during the same period.

$$
\text { CUF }=\frac{E_{t}}{H_{*} P} * 100 \%
$$

\subsection{Availability indices}

The availability of PV system includes Mean Time to Repair (MTTR) and Mean Time between Failure (MTBF) and availability. MTBF is the total time of accurate operation in a period divided by a number of failures. It increases after Preventive maintenance. MTTR is the total hours of downtime caused by system failures divided by a number of failures.
Mean time to Repair
$\mathrm{MTTR}=\mathrm{r}$
Mean time between Failure $\quad \mathrm{MTBF}=\mathrm{f}$ 


\section{International Journal of Science and Research (IJSR) \\ ISSN (Online): 2319-7064 \\ Index Copernicus Value (2015): 78.96 | Impact Factor (2015): 6.391}

$$
\text { Availability }=\frac{f}{f+r}
$$

The determination of the methodology for the increase in productivity due to system maintenance is shown in Figure 1.It shows the performance based reliability and availability assessment. The plant failure modes are identified on the basis of maintenance actions frequency, the output gets affected. If the maintenance actions are taken on time than the system productivity increases and if not then there is downtime in a system due to which the generation units get affected.

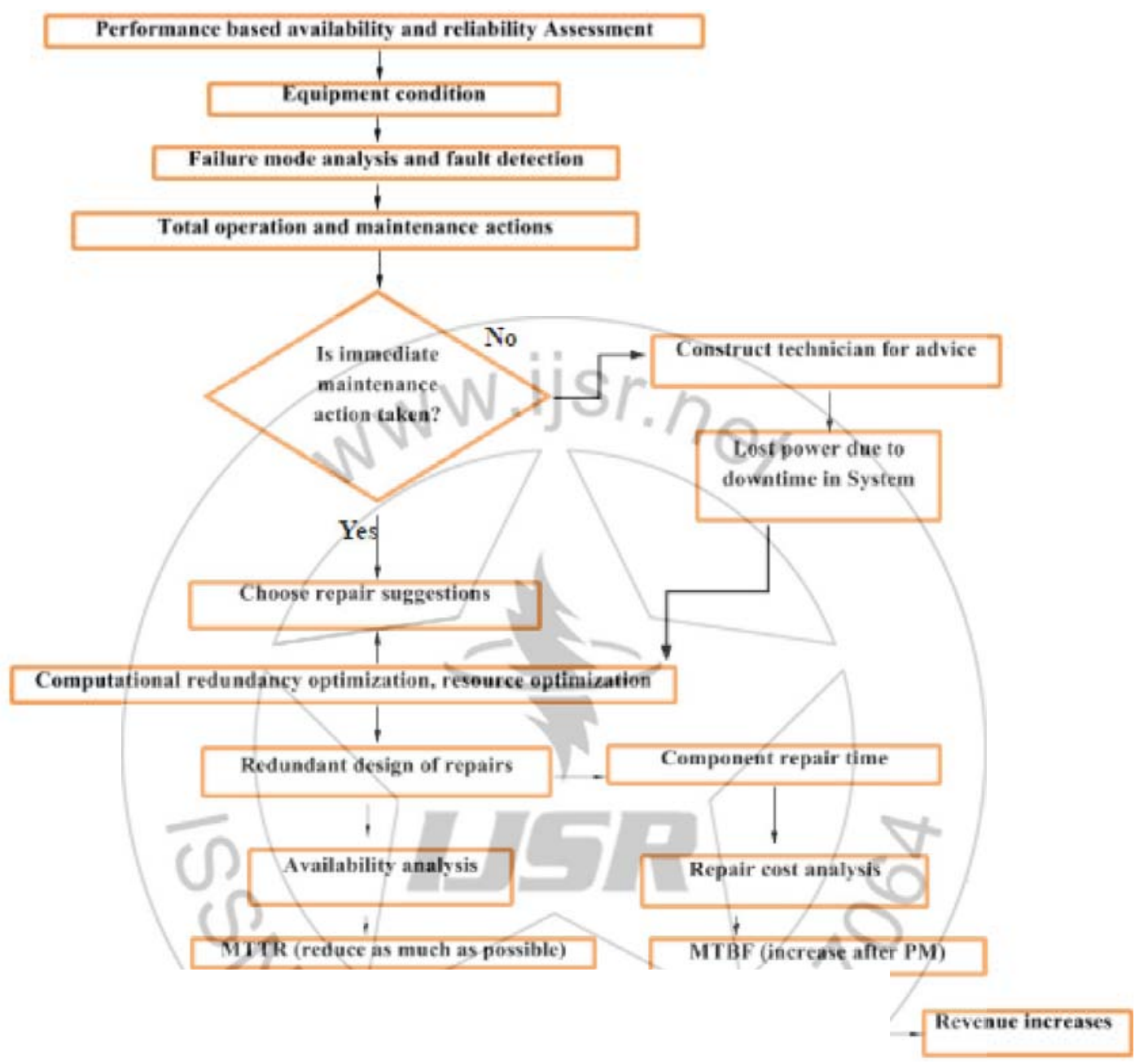

Figure 1: Layout of increase in productivity due to system Maintenance actions

\section{Results and Discussion}

\subsection{System Performance Evaluation of 1 MW PV System}

Solar irradiance absorbed by the PV modules is converted to useful power. The output power varies with the solar irradiance and ambient temperature. The daily average inplane solar radiation is observed from the weather station sited at the location for the period of January 2015 to December 2015. A typical monthly result is shown in Figure 2 to understand the effect of irradiance and temperature on the system output. The weather data from January 2015 to December 2015 are shown in Table 2. Normally, with the increase in solar radiation intensity a positive increase in output current of the solar PV module is observed. A positive increase in an output current is mainly due to the increase in a number of photons striking solar PV module which results in larger electron-hole pair generation and consequently higher photocurrent. The appropriate performance indicators which may be used to define the overall PV system performance with respect to energy production, solar resources and system energy losses, uptime, downtime, final energy generation, reference energy generation, PR, system loss and availability. The total energy generation normalizes the energy produced with respect to system size. Subsequently it is a convenient way to compare the performance of PV systems with different sizes. The reference energy generation represents the number of peak sun hours. It is a function of location, inclination and orientation of solar PV array. The total energy generation and reference energy generation is calculated by using Equations (1)-(2).

The monthly average solar irradiance varied from $600 \mathrm{~W} / \mathrm{m}^{2}$ in August to $1100 \mathrm{~W} / \mathrm{m}^{2}$ in February. The observed average

\section{Volume 6 Issue 1, January 2017}




\section{International Journal of Science and Research (IJSR) \\ ISSN (Online): 2319-7064 \\ Index Copernicus Value (2015): 78.96 | Impact Factor (2015): 6.391}

monthly energy generation trend of the system is shown in Figure 3. Average annual monthly energy generation of the plant is about $1515.55 \mathrm{MWh}$. Average annual monthly energy generation for last 3 years, 2013, 2014 and 2015 are 1605.6, 1537.42 and 1503.6 MWh, respectively. Maximum energy generation in the year 2015 is $151.66 \mathrm{MWh}$ in May 2015 and lowermost energy generation is $86.31 \mathrm{MWh}$ recorded in the month of July. It is concluded that the energy generation is mainly influenced by the ambient temperature and solar radiation. Annual average reference energy of the plant is about 1965.47 MWh. Average annual reference generation for last 3 years, 2013, 2014 and 2015 are 1925.35, 1976.93 and 1994.12 MWh, respectively. The data showed in Figure 3 indicates that energy generation is low in the months of July and August, due to a large number of rainy and cloudy days during these months. The average power output, monthly energy generation and annual energy generation by the PV plant are mentioned in the Table 3. The utmost useful parameter is PR, its value is very important for the identification of occurrence of problems either due to different system component failure or grid outages; nevertheless it cannot specify the cause. Average monthly PR for all system is shown in Figure 4.Average annual PR for the system during operating period is found to be $75.12 \%$. The average annual Performance ratio of last 3 years, 2013, 2014 and 2015 are $77.9 \%, 75.87 \%$, and $75.21 \%$ respectively. For a well-designed system, PR value must be greater than $75 \%$. The observed trend of PR follows the monthly radiation trend and negative trend of temperature as compared with Figure 2. The average annual capacity utilization factor over the last three years of operation was $17.67 \%$. Figure 5 shows the average monthly capacity factor over the operational year 2015.

\section{Performance comparison}

A comparison table of different existing solar PV plants from different locations is given in Table 4. Normalized performance parameters are used to compare different PV systems. Data collected using SCADA systems is helpful in evaluating the system sporadically to ensure its correct operation. The reason for higher PR compared to other locations is due to higher solar insolation in Western India, which is a fortunate condition to yield maximum energy from the solar PV technologies.

Table 2: Weather data of the site

\begin{tabular}{|c|c|c|c|c|}
\hline $\begin{array}{c}\text { Ambient } \\
\text { Temp }\left({ }^{\circ} \mathrm{C}\right)\end{array}$ & $\begin{array}{c}\text { Module } \\
\text { Temp }\left({ }^{\circ} \mathrm{C}\right)\end{array}$ & $\begin{array}{c}\text { Wind velocity } \\
(\mathrm{m} / \mathrm{s})\end{array}$ & $\begin{array}{c}\text { Irradiance } \\
\left(\mathrm{W} / \mathrm{m}^{2}\right)\end{array}$ & Month \\
\hline 24.54 & 38.75 & 1.8 & 228.33 & Jan-15 \\
\hline 28.77 & 46.41 & 1.7 & 260.77 & Feb-15 \\
\hline 32.94 & 49.84 & 1.9 & 269.6 & Mar-15 \\
\hline 36.06 & 49.51 & 2.4 & 294.65 & Apr-15 \\
\hline 37.05 & 50.15 & 3.4 & 294.65 & May-15 \\
\hline 34.94 & 42.71 & 3.5 & 210.35 & Jun-15 \\
\hline 33.55 & 42.25 & 3.1 & 192.78 & Jul-15 \\
\hline 32.5 & 40.1 & 2.7 & 151.88 & Aug-15 \\
\hline 32.75 & 45.5 & 2.1 & 214.37 & Sep-15 \\
\hline 34.12 & 48.63 & 1.2 & 249.11 & Oct-15 \\
\hline 30.71 & 43.28 & 1.3 & 225.74 & Nov-15 \\
\hline 36.4 & 38.71 & 1.6 & 249.134 & Dec-15 \\
\hline
\end{tabular}

Volume 6 Issue 1, January 2017
Table 3: Actual generation of the PV plant

\begin{tabular}{|c|c|c|c|}
\hline $\begin{array}{c}\text { Annual Energy } \\
\text { Generation }(\mathrm{kWh})\end{array}$ & $\begin{array}{c}\text { Actual Energy } \\
\text { Generation }(\mathrm{kWh})\end{array}$ & $\begin{array}{c}\text { Average power } \\
\text { output }(\mathrm{kW})\end{array}$ & Month \\
\hline \multirow{5}{*}{1503625} & 127689 & 786.02 & Jan-15 \\
\cline { 2 - 4 } & 131765 & 793.96 & Feb-15 \\
\cline { 2 - 4 } & 149037 & 842.01 & Mar-15 \\
\cline { 2 - 4 } & 146794 & 764.88 & Apr-15 \\
\cline { 2 - 4 } & 151661 & 712.92 & May-15 \\
\cline { 2 - 4 } & 112320 & 735.76 & Jun-15 \\
\cline { 2 - 4 } & 86309 & 685.02 & Jul-15 \\
\cline { 2 - 4 } & 99883 & 690.1 & Aug-15 \\
\cline { 2 - 4 } & 109392 & 810.56 & Sep-15 \\
\cline { 2 - 4 } & 140496 & 760.4 & Oct-15 \\
\cline { 2 - 4 } & 121468 & 732.8 & Nov-15 \\
\cline { 2 - 4 } & 126811 & 740.4 & Dec-15 \\
\hline
\end{tabular}

Table 4: Comparison of performance of grid-connected PV

\begin{tabular}{|c|c|c|c|c|}
\hline Reference & Year & PR & $\left.\begin{array}{c}\text { Capacity } \\
(\mathrm{kW}\end{array}\right)$ & Location \\
\hline$[13]$ & 1997 & 0.48 & 100 & Italy \\
\hline$[14]$ & $1999-2003$ & 0.75 & 60.4 & IKEA \\
\hline$[14]$ & 2001 & 0.72 & 34 & Corn Croft, Nottingham \\
\hline$[15]$ & 2007 & 0.65 & 67.84 & Univer Spain PVS-1 \\
\hline$[14]$ & 2004 & 0.69 & 22.1 & Campkin Court \\
\hline$[13]$ & 2002 & 0.73 & 50.4 & Northern Germany \\
\hline$[14]$ & 2004 & 0.62 & 60.4 & IKEA \\
\hline $\begin{array}{c}\text { Present } \\
\text { Study }\end{array}$ & $2013-2015$ & 0.75 & 1000 & India \\
\hline
\end{tabular}

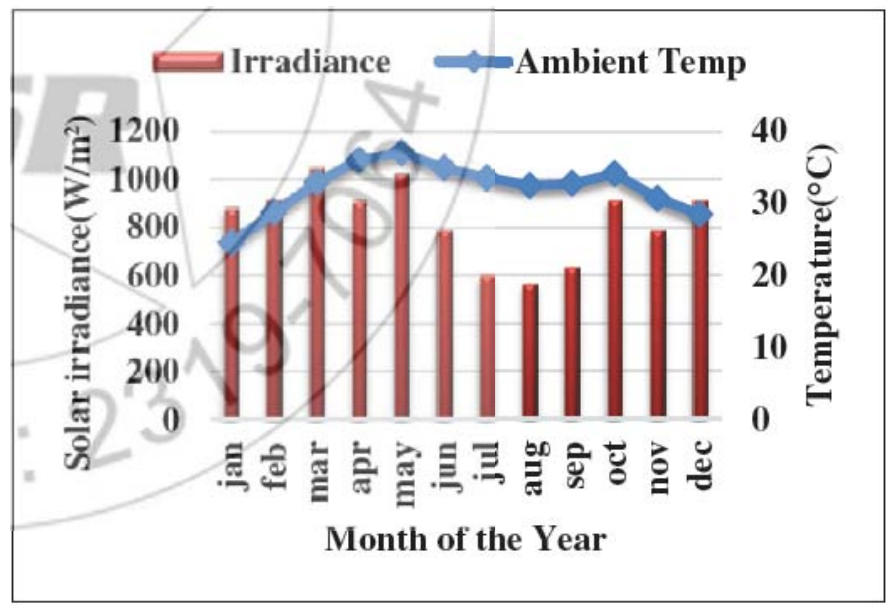

Figure 2: Average daily solar radiation and ambient temperature over the monitored period 


\section{International Journal of Science and Research (IJSR)}

ISSN (Online): 2319-7064

Index Copernicus Value (2015): 78.96 | Impact Factor (2015): 6.391

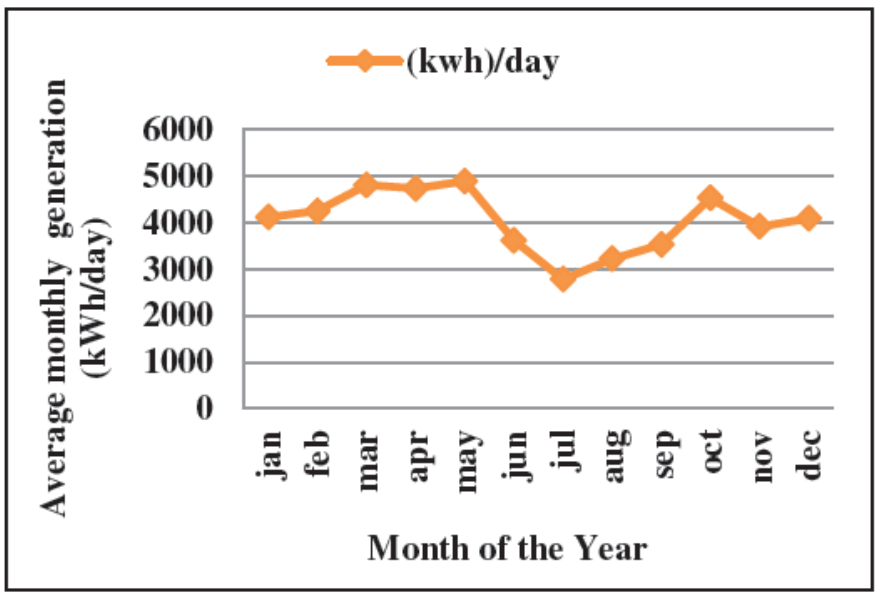

Figure 3: Monthly average energy generation of PV system

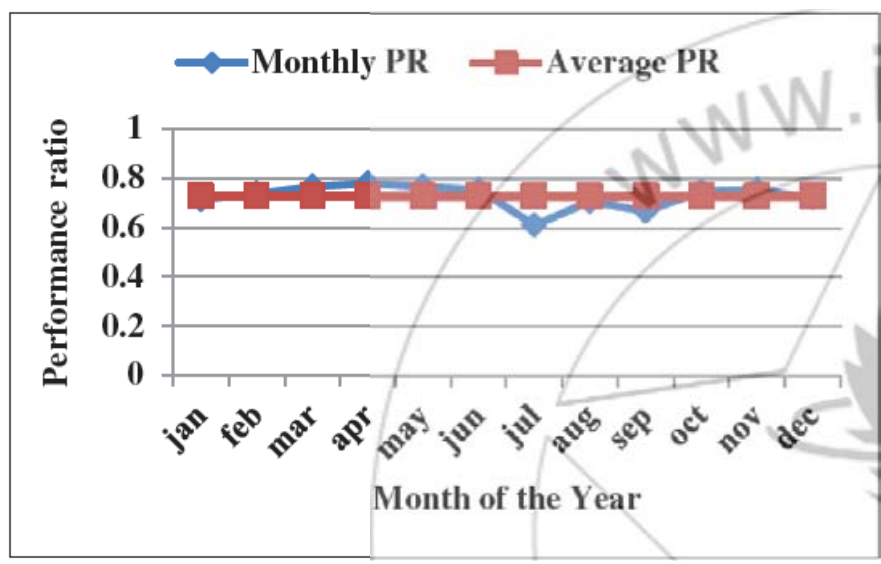

Figure 4: Average performance ratio of PV system

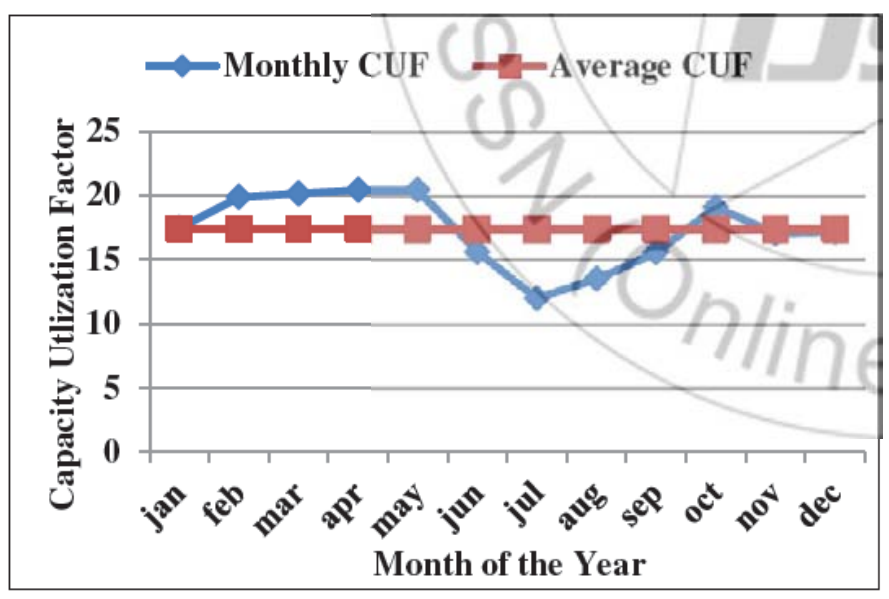

Figure 5: Average monthly capacity factor

\subsection{System O\&M Experience}

\subsubsection{Logistical downtime in system}

Downtime experienced by the system could be strategic or unintended. Unintended events could occur due to component failure or grid outage. Strategic events include Preventive or Predictive maintenance which comprises of (testing of components proper functioning, repair or replace components and performance level).Corrective maintenance could be either strategic or unintended. Therefore, maintenance steps require ensuring that the component is operational. Figure 6 shows total system downtime during the year 2015 which includes both strategic and unintended events affecting system availability and performance. Amplified logistical downtime could be due to unavailability of spare parts in time.

\subsubsection{Lost power production due the maintenance actions} In a case of component outages, whether planned or unplanned, it impacts the system's ability to generate output. Both preventive maintenance and corrective maintenance decision will influence on plants reliability and maintainability. Unscheduled maintenance agitates generation capacity and it requires human intercessions to restore the system back to operational capacity. [16] This analysis is used to capture maintenance service, failure events, replacements, and repairs. System monitoring includes failure events (what category of failure and why failure has recorded) and activity log dates (failures, repairs, and maintenance). Plant monitoring period was considered from January 1, 2015, to December 31, 2015. Over the period total, 40 unscheduled maintenance events were recorded. Failure events are shown in Figure 7. It demonstrates the breakdown of a component due to which generation capacity loss was witnessed. Failure events involved in the current study were observed with inverters, PV modules, transformer and system (which include blown fuses, burned connectors, cabling loss). Lost energy due to component failure is shown in Figure 8 which noticeably illustrates that how the plant reliability and maintainability affect the system operation, therefore impacts the energy production [19]-[22].

The study shows that, due to unscheduled events, the energy production got affected and hence it required manual human intervention to restore the system back to full operational level. These events could be as simple as exhaust fan failure, a manual restart of tripped inverter or considerably more complex such as damage due to surge or internal problem in the inverter. A single loss of PV module or a single fuse blown will not have any significant impact on a system unless it is for a single day or two which indeed has to be traced punctual as well. This interruption will show a negligible change in the average annual production but in the case of an inverter or a transformer, the issue is measurable. This particular situation will have much greater damage to a system. O\&M costs analyses were conducted from the system maintenance activity logs covering a period from Jan 2015 to Dec 2015. The result illustrates that due to unscheduled maintenance events the amount of repair cost is needed to bring the component back to service. The unscheduled maintenance repair cost is shown in Figure 9. It shows that the cost of maintaining inverters is much more than another component. The system collectively comprises of fuses, connectors, junction box and cabling issues.

\subsubsection{Component Maintenance actions}

Scheduled and Unscheduled maintenance events were conducted over the entire plant. Figure 10 shows the total 


\section{International Journal of Science and Research (IJSR) \\ ISSN (Online): 2319-7064 \\ Index Copernicus Value (2015): 78.96 | Impact Factor (2015): 6.391}

maintenance actions taken at the plant by different components, the consequence may diverge from one component to other. Scheduled maintenance was conducted every year since the plant came into operational. Table 5 shows the percentage of scheduled and unscheduled events occurred during the year 2015 .

Table 5: Total maintenance actions taken in system

\begin{tabular}{|c|c|c|c|}
\hline Total \% & Unscheduled \% & Scheduled \% & Year \\
\hline 75 & 11 & 64 & 2015 \\
\hline
\end{tabular}

\subsubsection{Component total repair time}

The time required to bring the plant back at normal operational level is stated as the repair time. It depends on the availability of spare parts if any fault has occurred, type of fault, also includes the availability of labor and travel distance from the location of the plant. Repair time fluctuates for the above conditions and accordingly contrasting from one system to another system. Figure 11 shows total component repair time that was analyzed on the given plant location during the year 2015. It shows that the majority of repair cost is allied with the inverters and transformers.

A detailed analysis of unscheduled events of the inverter was conducted. Classified into five categories, which are based on inverter operation namely, Matrix, design, interlock, controller and various others categories. Figure 12 shows inverter repair cost based on the above categories. The Matrix represents the power electronic inverter bridge, associated switching transistors, capacitor bank, heat sink and cooling fans. The Controller includes those circuit components and functions which are essential to control the power conversion and protective devices. Design includes cabinet weather protection. Interlock refers to the dc disconnect and door interlock alarm circuitry. Internal refers to fault conditions within the inverter which cannot be easily identified. Other categories capture events such as wiring, inoperative switches, and unknown event that signal a fault condition [10], [17][18]. In this analysis, the five matrix events cover modular fan functioning issue and replacement, switching transistor issue and its replacement, the two controller events indicated blown PCU card and replacement, the two internal events confirmed auto reset indication, the five different interlock events contains inverter auto trip and nesting rodents, the two other events involved loose connections, inverter at sleep mode and unknown cases.

Therefore, MTTR is calculated as $0.39 \mathrm{hrs}$. It is the average time of each downtime. MTBF is calculated as $72.60 \mathrm{hrs}$ which reveal that failure occurs in the system every $15.85 \mathrm{hrs}$ leaving it unavailable and engendering losses. As a result, we have an average time for each downtime, which concludes that for every $72.60 \mathrm{hrs}$ the system will be unavailable for $0.39 \mathrm{hrs}$. Consequently, the availability of the plant for the year 2015 was $99.46 \%$.

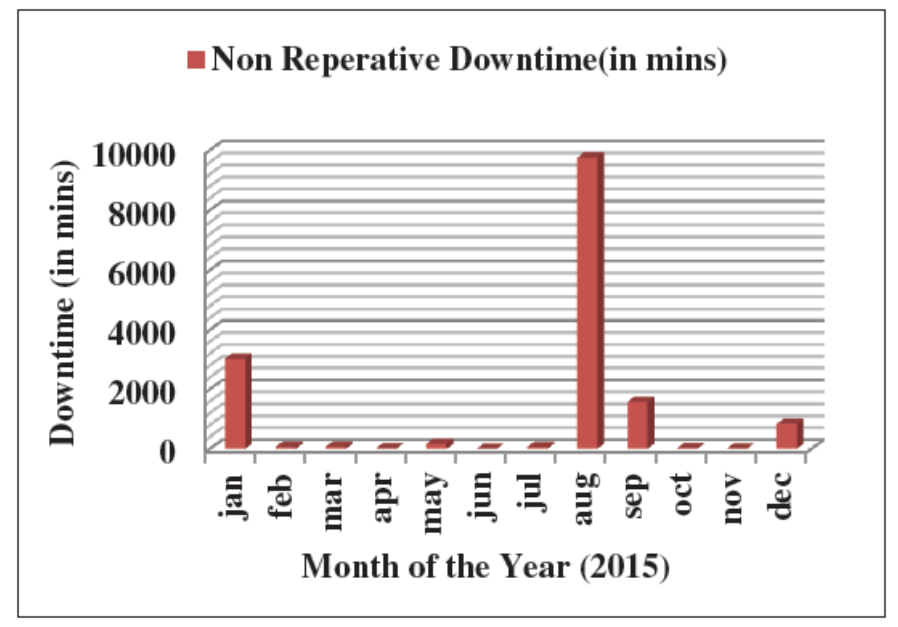

Figure 6: Logistical Downtime in system

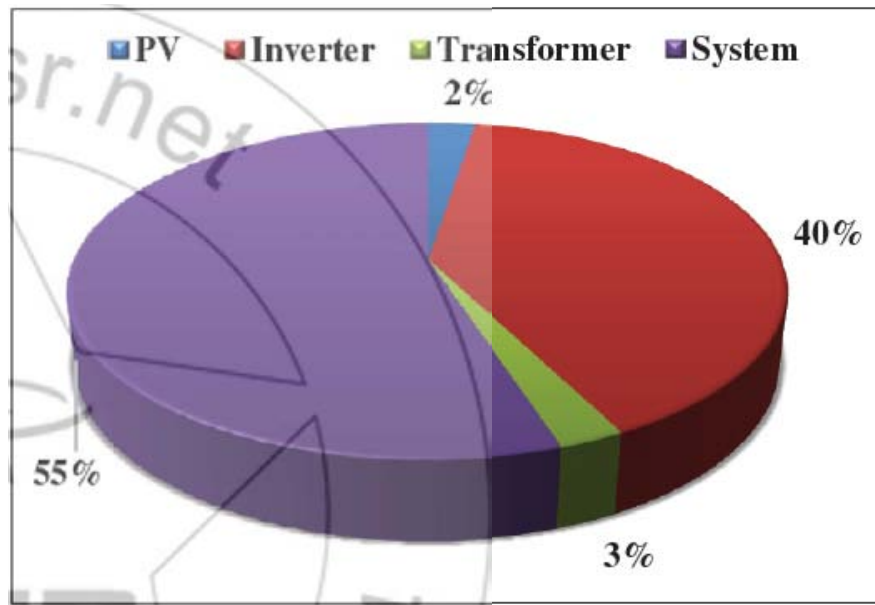

Figure 7: Unscheduled maintenance events by component

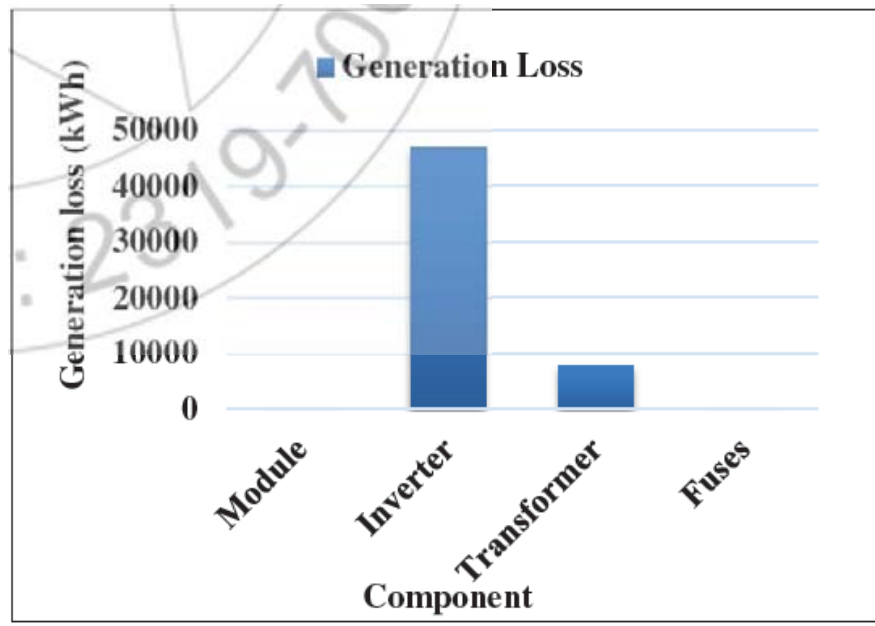

Figure 8: Energy loss due to failure events (2015) 
International Journal of Science and Research (IJSR)

ISSN (Online): 2319-7064

Index Copernicus Value (2015): 78.96 | Impact Factor (2015): 6.391

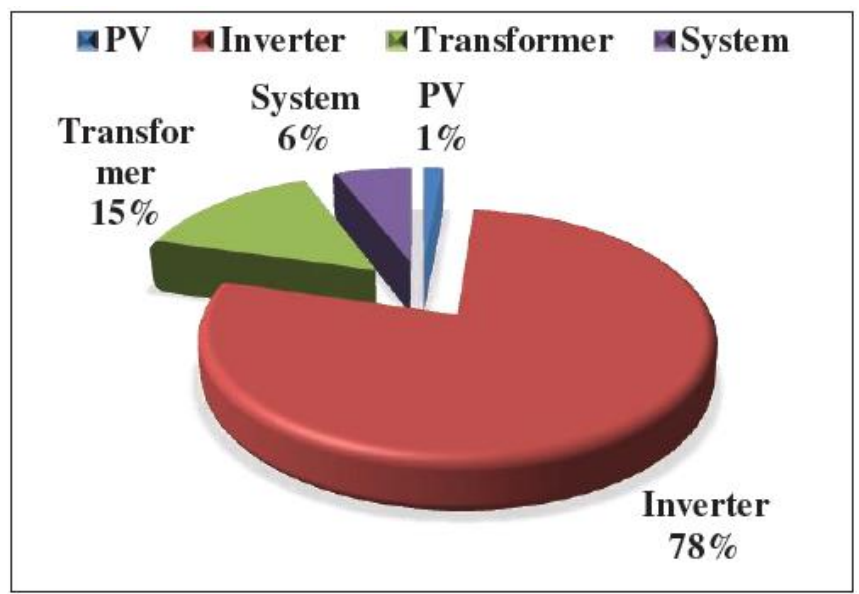

Figure 9: Unscheduled maintenance cost by component

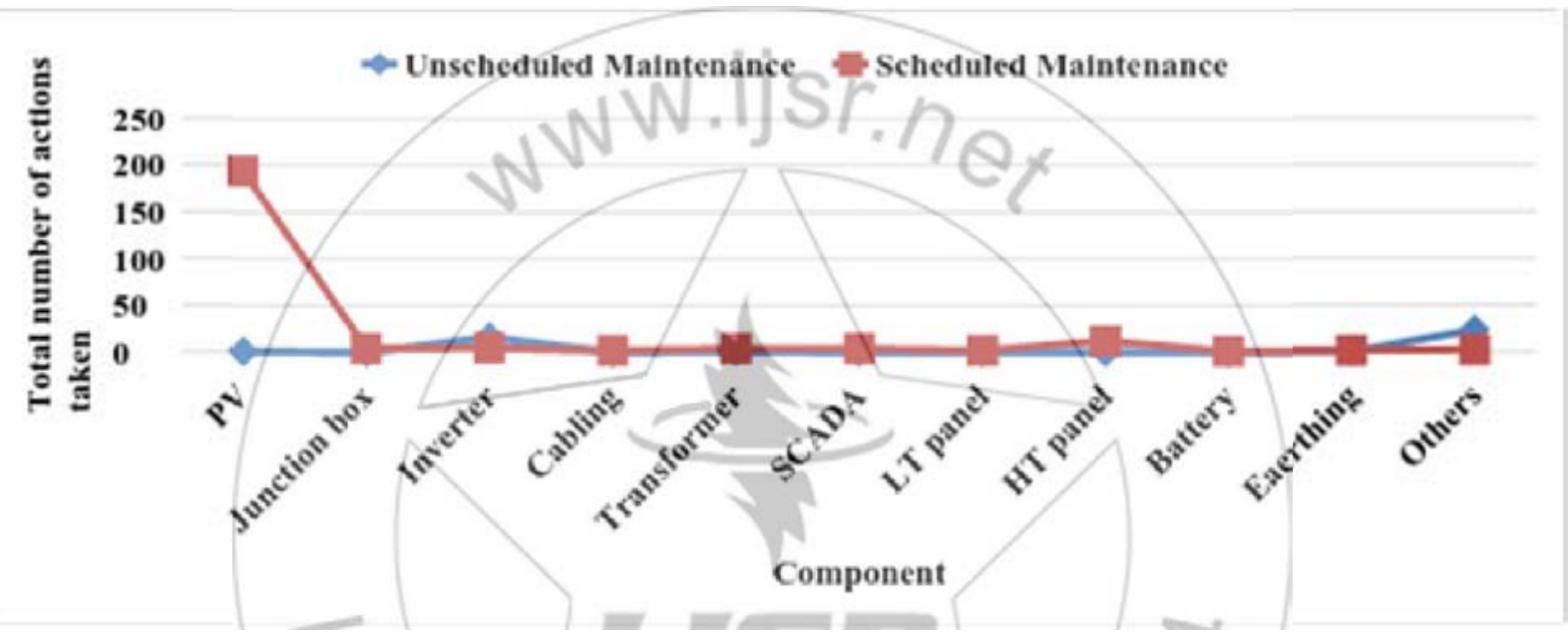

Figure 10: Total maintenance actions taken during the year 2015

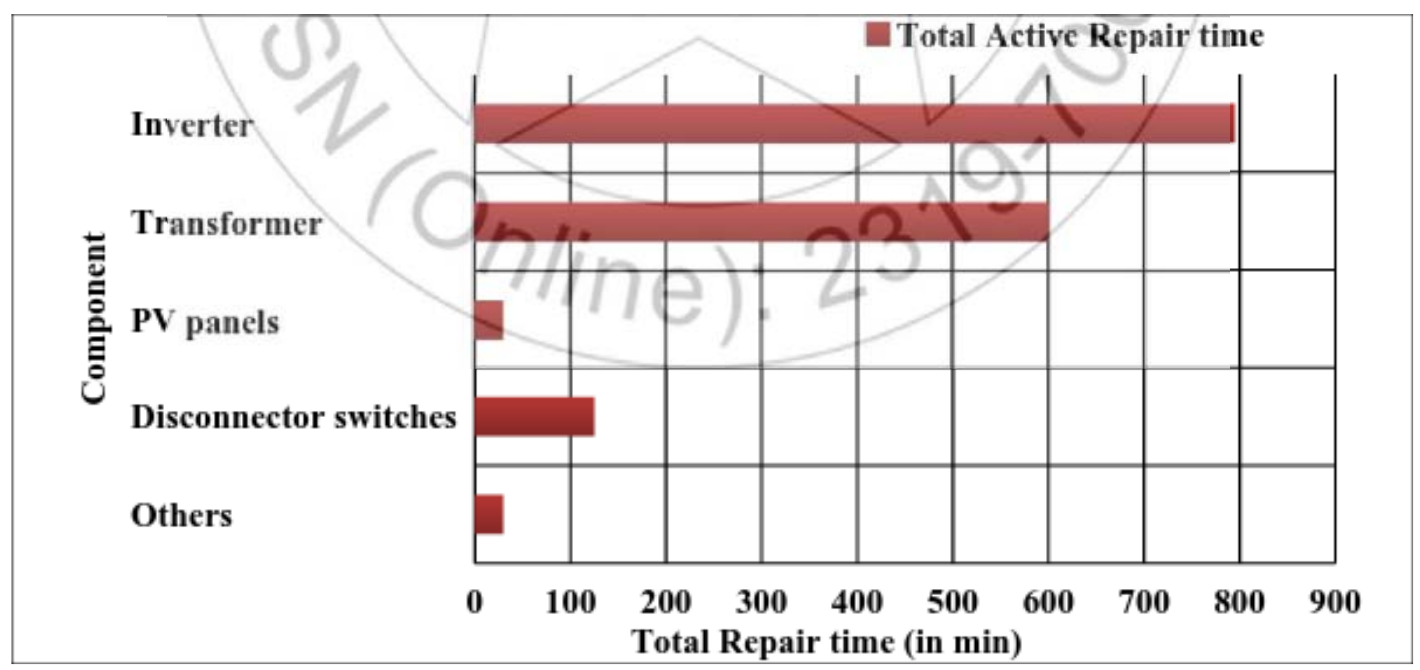

Figure 11: Component total repair time (in min) 


\section{International Journal of Science and Research (IJSR)}

ISSN (Online): 2319-7064

Index Copernicus Value (2015): 78.96 | Impact Factor (2015): 6.391

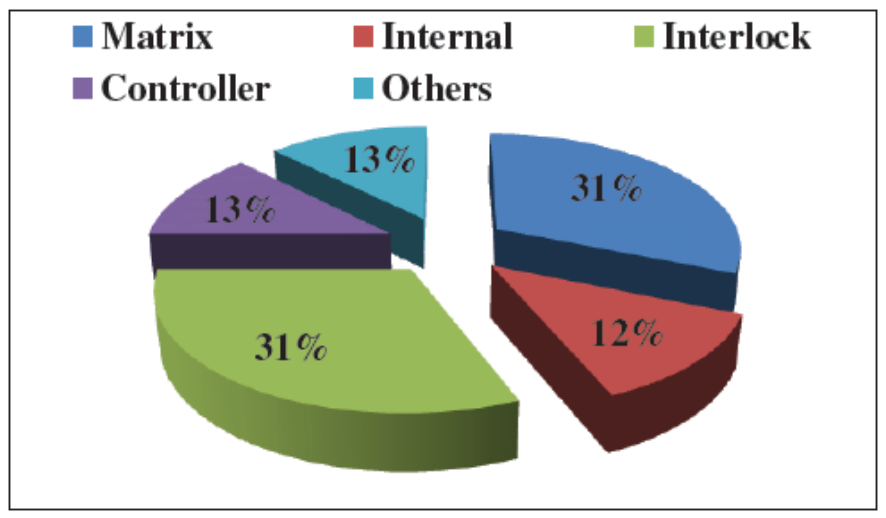

Figure 12: Inverter repairs by events and category

\section{Conclusion}

The study was conducted for solar PV energy generation for $1 \mathrm{MW}$ grid-connected installation under actual climatic condition. The energy data, performance evaluation, and O\&M experience provide a treasury of information. This paper provides numerous observations, including average annual energy generation $1515.55 \mathrm{MWh}$ in the year 2015. The highest recorded average monthly energy generation was 151.66 MWh in the month of May and lowest average monthly energy generation is $86.31 \mathrm{MWh}$ in the month of July. The plant is operating with the good amount of PR. The average annual PR for last three years, 2013, 2014 and 2015 were observed to be $77.9 \%, 75.87 \%$, and $75.21 \%$. The average capacity utilization factor of the plant was observed to be $17.67 \%$. The availability of the plant for the year 2015 was $99.46 \%$. The plant operates as per metered data and operating conditions of the system. The total MTTR is $0.39 \mathrm{hrs}$ and MTBF is $72.60 \mathrm{hrs}$. MTBF increases after PM, shows maintenance and substantiation methods are being well run and MTTR, the exertion is to reduce as much as possible to bring the plant to full operational level by doing appropriate maintenance on scheduled time.

\section{Nomenclature}

$\begin{array}{ll}\text { A } & \text { net plant area in square meter } \\ \text { AC } & \text { alternating current } \\ { }^{\circ} \mathrm{C} & \text { degree celsius } \\ \text { CUF } & \text { capacity utilization factor } \\ \text { DC } & \text { direct current } \\ { }^{\circ} \mathrm{E} & \text { degree east } \\ \mathrm{Em} & \text { energy production by the plant in } \mathrm{m}^{\text {th }} \mathrm{month}(\mathrm{kWh}) \\ \mathrm{Er} & \text { reference energy generation by plant }(\mathrm{kWh}) \\ \mathrm{Et} & \text { annual energy generation by the plant }(\mathrm{kWh}) \\ \mathrm{Ht} & \text { total-in-plane solar insolation }\left(\mathrm{kWh} / \mathrm{m}^{2}\right) \\ \mathrm{IEA} & \text { international energy agency } \\ \text { IRR } & \text { Internal rate of return } \\ \mathrm{kWh} & \text { kilo watt hour } \\ \mathrm{MTTR} & \text { mean time to repair } \\ \mathrm{MTBF} & \text { mean time between failure } \\ \mathrm{MW} & \text { mega watt } \\ \mathrm{MWh} & \text { megawatt hour } \\ \eta & \text { efficiency of photovoltaic module } \\ { }^{\circ} \mathrm{N} & \text { degree north }\end{array}$

$\begin{array}{ll}\text { O\&M } & \text { operation and maintenance } \\ \text { PM } & \text { preventive maintenance } \\ \text { PR } & \text { performance ratio } \\ \text { PV } & \text { photovoltaic } \\ \text { ROI } & \text { return on investment } \\ \text { W } & \text { watt } \\ \text { H } & \text { total number of hours in one year } \\ \text { P } & \text { total installed capacity of plant }\end{array}$

\section{Acknowledgements}

We would like to thank all the scientists of the solar group of GERMI for fruitful discussions, initiation, and coordination of this project. Special mention goes to Dr. Omkar Jani, Principal Research Scientist. The author would like to thank the Director General Dr. T Harinarayana, GERMI for their continuous encouragement to research.

\section{References}

[1] http://mnre.gov.in/grid-connected-solar-power-projectinstalled-capacity [accessed 31-10-2016].

[2] A.K Mishra, Anil Kumar Dubey, C.B Tripathi, Prahsant baredar Lala Tripathi.'Renewable energy: An overview of its contribution in current energy scenario of India," Renewable and Sustainable energy reviews, pp. 226-223, July 2016.

[3] K.Shudhakar B. Shiva Kumar, "Performance evaluation of 10MW grid-connected solar photovoltaic power plant in India," Energy Reports, October 2015.

[4] Solanki CS. Solar photovoltaic: fundamental, technologies and applications $2^{\text {nd }}$ India: Prentice Hall; 2011.

[5] Hemakshi Bhoye 1, Gaurang Sharma, An analysis of One MW Photovoltaic solar Power Plant Design, Vol. 3, Issue 1, January (2014) 2320-3765.

[6] International Energy Agency, Cost and Performance trends in grid-connected PV systems and case studies, Technical Report EA PVPS T2-06, Dec 2007.

[7] Ghiani E, Pilo F, Cossu S. Evaluation of photovoltaic installations performances in Sardinia, Energy Conversion and Management 2013;76:1134-42.

[8] K. Padmavathi, S. Arul Daniel Performance analysis of a $3 \mathrm{MW}_{\mathrm{p}}$ grid connected solar photovoltaic power plant in India, Energy Conversion and Management (2013) 615625.

[9] Mellit A. Pavan AM Performance prediction of $20 \mathrm{kWp}$ grid-connected photovoltaic plant at Trieste (Italy) using artificial neural network. Energy conversion and Management 2010; 84:807-21.

[10]L.Moore, and H.Post," Photovoltaic power plant experience at Tucson Electric Power" <Energy Conversion and Resources Journal> v.2005, p.387-394.

[11] Moore L. Post H, Hayden H, Canada S, Narang D. Photovoltaic power plant experience at Arizona Public Service - a 5-year assessment. Progress in Photovoltaic: Research and Applications 2005; 13: 353-363.

[12]IEC, "Photovoltaic System Performance MonitoringGuidelines for Measurement, Data Exchange and 


\section{International Journal of Science and Research (IJSR) \\ ISSN (Online): 2319-7064 \\ Index Copernicus Value (2015): 78.96 | Impact Factor (2015): 6.391}

Analysis IEC Standard 61724," Geneva, Switzerland, 1998.

[13] Jahn U, Nasse W. Performance analysis and Reliability of grid-connected PV systems in IEA countries. Proc. 3rd world conference on photovoltaic energy conversion; 2003[Osaka, Japan].

[14]IEA (International energy Agency), costs and performance trends in grid-connected photovoltaic systems and case studies. Report IEA PVPS T2-06; 2007 [accessed 7 July 2013].

[15] Drif M, Perez PJ, Aguilera J, Almonacid G, Gomez P, Casa J, et al. Univer Project A grid-connected photovoltaic system of $200 \mathrm{~kW}_{\mathrm{p}}$ at Jaen University. Overview and performance analysis. Sol Energy Mater Sol Cells 2007; 91:670-83.

[16] SEPA, "Utility solar asset Management and operations and maintenance".

[17] Bower W. inverters- critical photovoltaic balance-ofsystem components: status, issues and new millennium opportunities. Progress in Photovoltaic: Research and Applications 2000; 8: 113-126.

[18] Maish A. defining requirements for improved photovoltaic system reliability. Progress in photovoltaic Research and Applications 1999; 7 165-173

[19] Hasen T. The systems driven approach to solar energy: a real world experience. Proceedings of Solar Energy Systems Symposium, Albuquerque, NM, October 15-17, 2003

[20] Chouder A, Silverstre S, "Automatic supervision and fault detection of PV systems based on power losses analysis," Energy conversion and Management, vol. 51 pp.1929-37, 2010.

[21]C. Strob and P. Meckler, "Arc faults in photovoltaic Systems," in proceedings of the $56^{\text {th }}$ IEEE Holm Conference on Electrical Contacts, pp.1-7, 2010.

[22] A.D.S Wendlandt, T. Buseth, S. Krauter, p. Grunow, "Hot Spot Risk analysis on Silicon Cell Modules," in $25^{\text {th }}$ European Photovoltaic Solar Energy Conference and Exhibition/ $5^{\text {th }}$ World Conference on Photovoltaic Energy Conversion, Valencia, Spain, 2010, pp. 4002-4006.

\section{Author Profile}

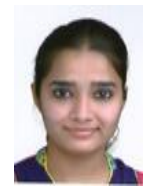

Jaya Vasita received the B.tech degree in Electronics and Communication in 2014 with honors and at current pursuing M.tech in Energy systems and Technology (Solar Energy) and also working as a Project Intern in Gujarat Energy Research and Management Institute and assisting for training under "National Certification Programme for Rooftop Solar Photovoltaic Installer.

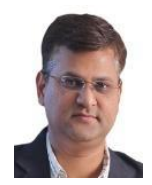

Prof. Akash Davda is working as a Senior Scientist at Gujarat Energy Research and Management Institute. He has pursued his $\mathrm{BE}$ and $\mathrm{ME}$ in Electrical Engineering, both with honors and is Bureau of Energy Efficiency (BEE), Govt. of India certified Energy Manager and Energy Auditor. He has a work experience of around 14 years in research, academics and administration. At GERMI, his profile includes handling and management of research and Renewable Energy projects, development and review of research proposals, working as Principal Investigator (PI) and Co-PI for various research and funded projects, contributing to reports, guiding PG students, working as Programme Coordinator for "National Certification Programme for Rooftop Solar Photovoltaic Installer". He has several research papers to his credit, in National and International Conferences and reputed International Journals. Akash is a member/life member of various professional bodies like Indian Society of Technical Education (ISTE), International Solar Energy Society (ISES), Solar Energy Society of India (SESI), Society of Energy Engineers and Managers (SEEM), Association of Computer, Electronics and Electrical Engineers (ACEEE) etc. 